\title{
THE PORTRAYAL OF ANDREJ HLINKA IN SLOVAK HISTORIOGRAPHY
}

\section{ABSTRACT}

The paper analyzes the course of the process of historical research of the personality of Andrej Hlinka. One of the most significant figures of the Slovak history in general became the subject of interest of the Slovak historians only gradually, slowly and with big difficulties. Nevertheless, historians' opinions which have been formed in particular period connections reflect specifically and typically the peripeties of the development of the Slovak national issue and phases of interest (disinterest) of historiography in this personality, and they represent a unique source of the view of collective historical memory of the national community, of the formally desired and naturally formed development of the community's notion of the values of its own past.

No historical monograph on Hlinka was published in 1939-1989. However, important references, period evaluations and observations can be found in synthetically oriented works of the following historians: František Hrušovský, František Bokes, Július Mésároš and Lubomír Lipták and others. The personality of Hlinka was either suppressed or evaluated one-sidedly negatively. The year 1968 brought a certain change in this direction and revaluation of Hlinka's personality. The period of normalization in $70 \mathrm{~s}$ and $80 \mathrm{~s}$ created a larger space to remember Hlinka's personality, however, its interpretation was again shifted towards negative side. The social and political change after 1989 and current state of research corroborate natural comeback of the personality in its environment, however, they also mirror a disproportion between spontaneously preserved "heritage of (the Slovak) historical memory" (heritage of the memory of majority of the national community, respectively) and institutionally created "memory of the heritage".

\section{KEYWORDS:}


The aim of this paper is to map in detail and analyse in depth the portrayal of Andrej Hlinka in historiography. It must be understood, however, that this involves not only the collection of bibliographic data but also an understanding of the historical context in which Hlinka lived, which then explains why his historiography was either not written, written with bias, or only mentioned in passing. We view historiography not only as a science pursuing its research subject (in this case, the historical figure of Andrej Hlinka) but as an important authoritative tool to maintain and cultivate the collective historical memory. At the same time, it is necessary to realize the problem Andrej Hlinka's portrayal proved to be in domestic historiography. This problem presented itself with other Slovak historical figures, all representatives of the noncommunist Slovak political elite of the first half of 20th century (e.g. Milan Rastislav Štefánik, Milan Hodža, Martin Rázus, Vavro Šrobár, Jozef Tiso, Štefan Osuský, Ivan Dérer and many others), who were intentionally tabooed, or whose actions were interpreted unilaterally. The persona of Andrej Hlinka ( ${ }^{*} 27$ September 1864 Černová pri Ružomberku - + 16 August 1938 Ružomberok) is a highly rewarding subject for historical research. He was a Slovak personality - a prodigy who, as a Roman-Catholic priest and politician, actively enriched Slovak society for a half century (from taking holy orders in 1889 practically until his death in 1938). This half-century can be divided into two major time periods, the first under Hungary until 1918, and the second under the Czechoslovak Republic.

During his ministerial work, Hlinka was already characterized by the following traits: a love of life, straightforwardness, uncompromisingness, strong-mindedness, tenacity, unyieldingness and rebelliousness. Due to his choleric temperament, these traits were often accentuated and sometimes developed into extreme forms, gestures and postures. In the environment of the parishes where he served, Hlinka proved to be an exemplary priest, keenly interested in his parishioners' problems. He established food and credit cooperatives; organized missions, theatres, lectures and moderation clubs; issued hymnbooks; and made efforts to get to know each parishioner personally. This led to a revival of religious life, an improved social situation and education, and the growth of the Slovak national consciousness.

Hlinka was one the founders of the independent Slovak People's Party in 1905. It was from this party - which had a democratic platform including the general right to vote, freedom of assembly and association, national rights, and the rights of lower social classes - that the greatest number of Slovak deputies were elected to the Hungarian Parliament. For his activities, Hlinka found himself pressed in on all sides. He was persecuted by the state authorities for his articles and political 
agitation, by the municipal representatives of the town Ružomberok for pointing out corruption, and by the church authorities as well. His bishop Alexander Párvy suspended him, removing him from the parish office and prohibiting him from performing priestly duties.

Hlinka was not, in effect, a rebel and rioter as such but first and foremost a fighter. His motto of "Life for God, freedom for the nation" was the embodiment of Slovak political efforts, expressing faith in both Christian and national principles, as well as a readiness to sacrifice for them. The political process of 1906 and, in particular, the tragic events of 1907 in Černová (Hlinka’s hometown) - where Hungarian civil guards shot 15 people attempting to forcibly consecrate the church - and made Hlinka, on the one hand, a living symbol of the oppression of Slovaks in Hungary, and on the other, a symbol of resistance, persistence and defiance. Černová, and by it Hlinka, made the Slovak issue visible to the world. In spite of general expectations, Hlinka won his dispute for clerical credit against Bishop Párvy, the Holy See siding with him against the bishop. It also appeared that Hlinka was not alone but that some persons of consequence abroad were standing up for him. His imprisonment for 2 years and 9 months did not break his spirit.

Hlinka's actions contributed significantly to the formation of the Czechoslovak Republic. It was he who resolutely directed hesitant Slovak politicians in May 1918 and clearly expressed his position in favour of the establishment of the Czecho-Slovak State. He quickly came to the conclusion, however, that the substance of such a state would not meet his original expectations. The conservative Slovak Catholic wing was excluded from the mainstream. The majority of politicians in the government automatically identified Catholicism with the old Austria-Hungary. Attacks against the Catholic Church, open anti-Catholic and often even anti-religious agitation along with the fear of the spread of radical socialism led Hlinka to the opposing position in favour of the restoration of the Slovak People's Party in December 1918. That party gradually obtained the highest number of voters in Slovakia. The concept of Slovak national independence was renewed in opposition to the concept of "Czechoslovakism", and the idea of Slovak autonomy was renewed in direct contrast to Prague centralism. Thus, the figure of Hlinka once again arose as a symbol, this time as a fighter for the preservation of the religious, national and cultural identity of Slovaks within the Czechoslovak Republic (CSR). The more this symbol was opposed and attacked, the livelier and timelier it became.

The issue of Slovak autonomy within the CSR was a minor platform detail promoted in parliament. Hlinka again appeared in the centre of an oppositionary political fight. As he had started his political fight while imprisoned in Hungary, he continued 
in a similar manner in the CSR with a trip to the peace conference to Paris where he spoke about the Slovak issue and the Slovak right to autonomy.

At that time, Slovakia was predominantly patriarchal, agrarian and Catholic while the new situation of the CSR meant an influx of new phenomena, unexpected and often unwanted changes requiring people to adapt to them. It meant an upheaval of the known world where Slovaks had lived until that time. This explains, to a certain extent, why a significant part of the Slovaks in opposition identified with Hlinka in particular and quite quickly, essentially beginning with his 60th birthday in 1924, started to accept him and address him as 'father' or 'daddy', as the national leader and the greatest living Slovak. The honour shown to him, which sometimes took the traits of a cult, should be understood as a consequence of his personal charisma (his patriarchal and compact appearance in black clerical vestments, clean-cut features with aquiline nose and blue eyes, a rich voice with nasal resonance, used to express himself clearly). It was also in reaction to the spreading honour, even cult-like respect accorded the President of the CSR, T.G. Masaryk, who was also called 'daddy'. However, Masaryk was often seen by the Slovak Catholics as the embodiment of the anti-Catholic mainstream. Hlinka was a politician who embodied the tradition of the Slovak opposition thinking, a resistant mentality, defiant rather than peaceful, conciliatory and compromise-oriented. He was a priest: a humble servant of God, but at the same time a fiery prophet and warrior of God, a creator and a relentless critic and destroyer at the same time.

Andrej Hlinka can be considered as a co-creator of the modern Slovak political ideology based on the principles of Slovak national independence and the right to self-governance. He should be also viewed as the co-creator of the environment which led to the formation of the modern Slovak political nation during the inter-war period. He was a man of paradoxes. This fact has already been encoded in his surname. "Hlinka" is a soft, malleable rock-like clay. However, Hlinka was a personality characterized by intractability and intransigence. Although Hlinka was a local public servant, he contributed to the opening of the Slovak issue in the world. He remained a local patriot of the Liptov region in his heart while creating a Slovak political system on a national scale. He was a humble priest and servant of God, and at the same time also a champion of the people, orator and agitator. He opened Slovak politics up to democracy and its principles while introducing an authoritative element into it as well. No matter what else he did, he enriched it with the male precept of determination and principle. 
Historical conditions for a systematic clarification of the figure of Andrej Hlinka by Slovak historiography were very unfavourable. External disfavour was determined by the political situation while internal disfavour was determined by the problem of how to approach this figure which represented a symbol. Hlinka and his life constituted a primary subject of interest among journalists and publicists. It is understandable that his first biographies were written by Karol Sidor, a journalist, editor, dramatist, politician and member of Hlinka's Slovak People's Party. As a citizen of Ružomberok and a close associate of Hlinka, Sidor considered himself to be an expert in his life and follower of his political ideology. He published the first version in honour of Hlinka's 60th birthday. ${ }^{1}$ A remarkable 60 thousand copies were published, along with a special edition of 12 thousand in the USA in 1926 . He published the second, more extensive edition in honour of Hlinka's 70th birthday. ${ }^{2}$ Although Sidor lacked a historical education, he was experienced in working out historical topics of modern Slovak history. The motive of his monumental work about Hlinka, which was censored by the state several times, consisted of emphasizing Hlinka's merits and presenting an apologetics of Hlinka's life and political ideology. According to Sidor, "Hlinka's person is the bearer of Slovak efforts and the catalyst for further action in the culmination of Slovak politics. Reading his biography is reading the political history of Slovaks, reading the teacher's words which will live forever." ${ }^{3}$ Nevertheless, we should admit that Sidor made some effort at objectivity. He realized the importance and benefit of hindsight, and so he ended Hlinka's biography with 1926 . He justified this by saying that the events after that year "are still in readers' fresh memory.... Such events are still painful for many of them, many of them understand them differently, and whereas my book should not be polemical, I had to omit such events and describe stories and events only up to 1926. They are not painful, offensive or outrageous anymore for anybody. They belong to history; they are ready to be immortalized in this book, to constitute part of Andrej Hlinka's biography up to 1926." Sidor wrote Hlinka's biography so that Hlinka stands out in each historical situation and is portrayed as the most important Slovak politician. It is interesting that the Czech publicist and translator Václav Cháb ${ }^{5}$ tried to compile Hlinka's biography on the occasion his of 70th birthday. Cháb was a former Czechoslovak legionary and dealt with history, in particular with the profiles of some Czech figures. However, he was not a historian and his left-wing political and world view was completely in contradiction with that of Andrej Hlinka. His book

\footnotetext{
1 K. Sidor, Andrej Hlinka, Bratislava 1924, 32 p.

2 K. Sidor, Andrej Hlinka (1864 - 1926), Bratislava 1934, 565 p.

3 K. Sidor, Andrej Hlinka (1864 - 1926), Bratislava 1934, p. 8.

4 K. Sidor, Andrej Hlinka (1864 - 1926), Bratislava 1934, p. 8.

5 V. Cháb, Andrej Hlinka. Život a politika, Praha 1934, 204 p.
} 
about Hlinka was published by the anti-religious publishing house Free Thought ("Volná myšlenka" ). In Chába's view the fight for Slovak independence was "in fact the fight for a power position for the Church, resistance against the invasion of the school of thought from the West.... The whole life of Hlinka is otherwise split into series of illogical changes and turns unless all its parts are integrated by such a fight for a power position for the Church." In his opinion, Hlinka himself is "... the type of Counter-Reformation zealot like those travelling across the Czech and Moravian lands after the Thirty Year War. He does not have a bit of modern understanding of the other's way of thinking, work and merits. He is predominated by clerical combativeness and a Counter-Reformation attitude towards all those who are not Catholic or those Catholics not belonging to his camp. He educated and created himself as such before the war. Such he will remain and come into history. He will come into history as a man who had a major influence on the masses and who maintained such influence on those masses at any cost until the end of his days."' Both Hlinka's biographers shared the opinion that combativeness is his fundamental trait, but they arrived at completely opposing interpretations of the person of Hlinka and its place, role and significance. For Sidor, Hlinka was a central hero tied to the internal logic of the Slovak history while for Chába, in contrast, he was an unpleasant relict of the past, an obstacle to the Czechoslovak national unification.

A month after Hlinka's death, in September 1938, the Munich Agreement was signed. The period of democracy came to an end and immediately afterwards, on 6 October 1938, the autonomy of Slovakia was declared and then, on 14 March 1939, the Slovak Republic was formed. The party previously led by Hlinka came to power. How his figure was interpreted became important to confirming the legitimacy of the new authoritarian political regime. Photographs and busts of Hlinka were placed in schools and offices; squares, streets and institutions were named after him. Officially, only superlatives could be used when speaking of him. He became the object of an official cult; however, no critical work was written by a historian in which his life and work were evaluated. There was, among other things, a lack of necessary hindsight. The needs of the general public were met by occasional articles in the daily press or the works of Karol Sidor - Notes from Mírov (Zápisky z Mírova) ${ }^{8}$ - and Ladislav Gejza Fagul'a (1908 - 1998) - Andrej Hlinka ${ }^{9}$. These were not historical works written by historians, however. Slovak historian František Hrušovský, who was also a deputy of

6 V. Cháb, Andrej Hlinka. Život a politika, Praha 1934, p. 196.

7 V. Cháb, Andrej Hlinka. Život a politika, Praha 1934, p. 202.

8 K. Sidor, Zápisky z Mírova, Bratislava 1941, 105 p.

9 L. G. Fagula, Andrej Hlinka. Bratislava 1943, 177 p. 
the Slovak Assembly for Hlinka's Slovak People's Party (HSL'S), published Slovak History (Slovenské dejiny) ${ }^{10}$ with the Matica slovenská (Slovak Source) publishing house in 1939. It was the first modern, popular synthesis of Slovak history. It was issued in several editions, and a condensed edition was used as a secondary school history textbook. Hlinka was included in the book in the context of Slovak political life while his significance and the events related surrounding that political life were given more attention. Hlinka was also quoted numerous times." This is related to Hrušovsky's concept of Slovak history being the history of the Slovak nation, and in modern times its effort to attain nationhood. In Hrušovskýs work, Hlinka became a symbol of the fight for the rights of Slovaks within Hungary and afterwards in the first Czechoslovak Republic. Despite a certain tendency, the author maintained some level of objectivity avoiding polemics and ostracism with respect to both Hlinka's opponents and the pathetic glorification.

The situation radically changed after the arrival of the Red Army in 1945. The Czechoslovak Republic was re-established, Hlinka’s Slovak People's Party (HSL'S) was prohibited and the formerly-supported Hlinka cult ceased to exist. The figure of Hlinka became unwanted for the new regime, because it was composed of Hlinka's former political opponents, which included the Communist Party. Due to his clear anti-Communist stance and his opposition to Prague-centrist governance, Hlinka was unacceptable to the new political leaders. Not only did his cult disappear but, by official order, any external signs of respect commemorating him in public were removed (including names of squares, streets, associations, statues, busts, portraits, postcards, and postage stamps). Historian František Hrušovský, who was exiled in 1945, wrote an article in 1946, "Why Andrej Hlinka is not mentioned in Slovakia today" (Prečo sa dnes na Slovensku nespomina Andrej Hlinka). He highlighted, on the one hand, the significance of Hlinka and the task awaiting historical science: "Many books and studies should be written about individual periods of Hlinka's career and work. Hlinka's work in various religious and clerical, cultural and educational, economic and social and national fields of life and individual stages of his political fight should be studied thoroughly and in detail, clarified, systematically evaluated and presented appropriately so that we can know and understand the person of Andrej Hlinka in its multiple relations to the whole Slovak national life and in its various manifestations in the development and creation of our national fortunes." ${ }^{12} \mathrm{He}$ could see, on the

10 F. Hrušovský, Slovenské dejiny. Turčiansky Sv. Martin 1939, 448 p.

11 F. Hrušovský, Slovenské dejiny. Turčiansky Sv. Martin 1939, p. 340, 370 - 371.

12 Literárny archív Slovenskej národnej knižnice Martin, fond F. Hrušovský - dodatky, k. 1. F. Hrušovský: Prečo sa dnes na Slovensku nespomína Andrej Hlinka. (Rukopis). 9. 1.1946. 
other hand, that the political situation was not favourable to deal with and analyse Hlinka's life. He knew well the fact that the tactic was to suppress the figure of Hlinka: "Disregarding Andrej Hlinka by passing over his merits and his significance in silence, trying to delete this name from the memory of the Slovak nation is a provocation which shall offend each Slovak.... Nothing is said or written about Andrej Hlinka in Slovakia today, there is no place for Andrej Hlinka in Slovak history, Andrej Hlinka has no access to the contemporary Slovak school, Slovak youth, to various strata of the Slovak people, because the present rulers arranged that, in the spirit of the Bolshevik good practices, even the name of Hlinka would not be mentioned, and thus the memory of Andrej Hlinka would completely fade from the Slovak nation." ${ }^{\prime 3}$ Silence with respect to Hlinka meant for Hrušovsky' "the best evidence of the moral strength of Hlinka's memory". The tactics of intentional concealment cannot be explained only as a reaction to the former official cult of Andrej Hlinka fostered during the period of the first Slovak Republic and before 1945. At that time, taking into consideration the public opinion as well, those in political power did not consider it necessary and inevitable to openly speak out against Hlinka as a negative figure in Slovak history. In his reflections, Hrušovský presents an interesting opinion that figures of the past are not attractive for new political leaders as they prefer concentrating attention on themselves: "In Slovakia we have never had so many kinds of 'heroes' as today. Those little and very much 'heroes' are able to celebrate each other on any occasion, they claim every possible credit, fostering each other, so it is no wonder that such 'heroism' cannot be shared with anybody else, and consequently even such a Slovak as Andrej Hlinka used to be cannot be recognized by them as a national hero." ${ }^{\$ 14}$ Hrušovský encountered here a very sensitive problem of the continuity and discontinuity in modern Slovak history, which cardinally concerned its figures, including Hlinka. They started from zero. Although the new political elite promoted in fact a very similar statehood programme as Hlinka had, it neither wanted nor could openly advocate it.

There was a very narrow space for scientific historical research into Andrej Hlinka. He was not acceptable to the political leaders after 1945. During the time of political struggles and changes, neither was the social atmosphere suitable for such research to be carried out. Thus, the figure of Hlinka and its evaluation became part of syntheses of Slovak history. A synthesis by historian František Bokes deserves special attention: "The history of Slovaks and Slovakia since ancient times until now" (Dejiny Slovákov a Slovenska od najstarších čias až po prítomnost') published in 1946 by the Slovak Academy of Sciences and Arts as part of the "Slovak national history

13 F. Hrušovský: Prečo sa dnes na Slovensku nespomína Andrej Hlinka. (Rukopis). 9. 1. 1946.

14 F. Hrušovský: Prečo sa dnes na Slovensku nespomína Andrej Hlinka. (Rukopis). 9. 1. 1946. 
and geography" project (Slovenská vlastiveda). The author wrote the book from the spring of 1944 through to the summer 1945, i.e., during the period of crucial events. He ended it, however, with 1920 . He maintained a balanced and realistic attitude towards the figure of Hlinka. He managed to include it in the historical context of newer Slovak history, not emphasizing Hlinka's individuality and dominance over others. According to Bokes, a dominant position in the Slovak national life at the end of the 19th century belonged to three personalities: Andrej Hlinka, Vavro Šrobár and Milan Hodža, who actively directed the destinies of Slovaks for a half-century. In his opinion, they represented Slovak political and national affairs and were distinct from each other, but they had one background in common - the Slovak common people. According to Bokes, "... each of them differently, but still with unanimous direction at the national liberation of Slovaks.... While V. Šrobár became a representative of the renewal efforts following the example of the Czech rejuvenating movement, Andrej Hlinka represented belligerent nationalism relying on Catholic layers within the nation, and M. Hodža, the youngest of the three, became the proponent of efforts which should have ensured the most advantageous position for Slovaks through the inclusion of Slovak issues into Central European politics. We cannot claim that these three representatives of the Slovak future differed fundamentally from each other whereas they were deeply rooted and grew up in a domestic environment, not to mention the influence of traditions created by preceding Slovak generations ... they endeavoured to base their national and political work on the broader masses of people." 15 Bokes devoted enough space not only to the question of the nomination of Hlinka to the position of the priest for the town Ružomberok, the dispute with Bishop Alexander Párvy from Spiš, the Černová tragedy in 1907 in which Hungarian civil guards shot 15 people attempting to consecrate the church, but also to Hlinka's support of the formation of the Czechoslovak Republic in 1918, the reasons for the renewal of the Slovak People's Party, and Hlinka's journey to the Peace Conference to Paris in 1919. He evaluates aptly also the motivation of Hlinka's political activity in 1918, explaining that, "at the outset of building new Slovakia, Hlinka and Hodža did not receive the task they deserved due to their past. This is why Hodža as a result of his not very positive actions in Pest and A. Hlinka for personal reasons did not stay long, hand in hand with Dr. Šrobár at the cradle of the new Slovakia. Many mistakes arising from such antagonism had then, undoubtedly, not a negligible but even a fatal effect on the future fate of Slovakia." 16

15 F. Bokes, Dejiny Slovákov a Slovenska od najstarších čias až po prítomnost', Bratislava 1946, p. 299.
16 F. Bokes, Dejiny Slovákov a Slovenska od najstarších čias až po prítomnost', Bratislava 1946, p. 379. 
When the power in the country was fully assumed by the Communist Party in 1948 , Slovak historiography fundamentally changed. Official historiography had to be political and follow Marxist-Leninist ideology (i.e., the class struggle, the working-class movement, the history of economy, the history of the Communist Party). It meant re-interpreting history from the ground up and eliminating anything other than the official interpretation. It was a huge strain on the historical memory and, at the same time, a blow to the work of historical figures. The class struggle and revolutions were considered crucial for the Marxist-Leninist interpretation of history. Consequently, masses of people, not figures, were determined to be crucial in history. Moreover, Slovak political efforts in history were evaluated as negative, as Slovak bourgeois nationalism, hostile to the interests of the working class. An intensive campaign against the Slovak bourgeois nationalism lasted from 1950 until the mid-1960s. The first Marxist theses, which served later for the creation of new syntheses of the history of Slovakia, were published by the Communist Party order as an appendix to the History Journal of the Slovak Academy of Sciences entitled History of Slovakia (Theses) (Dejiny Slovenska (Tézy)) in 1955. The revival of the Slovak political movement through the Hungarian People's Party is evaluated here as follows: "Thus the 'Ludak-clerical' group was formed within the wing of the Slovak bourgeoisie as a consequence of the political agitation of the Hungarian People's Party. The party (Néppárt) was established by Count Zichy on instructions from the Vatican (in 1894) and in its nature was reactionary and permeated by anti-Semitism." ${ }^{.7}$ Only several marginal notes are devoted to Hlinka: "Only Ludak clerics tried to attract masses of people concentrating on the most underdeveloped rural masses hampered by religious prejudices. A. Hlinka was a representative of such politics. ${ }^{118}$ During the interwar period, Hlinka's Slovak People's Party (HSL'S) was categorically evaluated negatively as a reactionary nationalistic party which, in fact, fostered the interests of the bourgeoisie and in the 1930s it made efforts as a fascist party together with other bourgeois parties to establish a fascist dictatorship. ${ }^{19}$ These theses served as the basis not only for syntheses but also for various publications, studies and articles. It was not an objective evaluation of the figure of Hlinka by historiography, but rather just critical political and ideological statements for political and propagandistic purpose only. Historical science was fully sold out to ideology. The topics seemingly dealt with by scientific methods had only their external form with which to provide weight to ideological arguments. Hlinka appears in such publications in the context of "coping with" the Slovak "Ludaks" as

17 L'. Holotík red., Dejiny Slovenska (Tézy), Bratislava 1955, p. 162.

18 L. Holotík red., Dejiny Slovenska (Tézy), Bratislava 1955

19 L'. Holotík red., Dejiny Slovenska (Tézy), Bratislava 1955, p. 249. 
a historical and social phenomenon, a reactionary manifestation, the rest of which should be combated in society. This is not mere chance, as such an approach was tied to the attempts of the communist-centralistic regime to criminalize any Slovak statehood ambitions existing in the centrally-governed state. History here served as an instrument. Terminology and textual apparatus gave only the impression of scientific quality. Science was sacrificed in favour of ideology and propaganda. So the works by a historian and propagandist rolled into one tried to change the historical memory by withholding or providing a one-sided, negative portrayal of the person of Hlinka. A typical example is Treason and Fall (Zrada a pád) of $1958^{20}$ by the Czech economic historian Imrich Stanek, also published in Polish in 1962. According to Stanek, Hlinka and his party spread "the poison of bourgeois nationalism"21 in the guise of Slovak autonomy. Stanek falsely tried to persuade readers that Hlinka did not lift a finger to help the formation of the Czechoslovak Republic, but he defended the positions of Hungarian patriotism. ${ }^{22}$ In his words, Hlinka was "the embodiment of obscurantism, mystics, conservatism, bigotry, demagogy and inconsistency - all typical traits by which the People's Party and the whole Slovak clerical fascism was characterized." ${ }^{23}$

Of similar nature is the work by Miroslav A. Huska, a well-known ethnographer who wrote a political pamphlet Against the people via falsehood (Proti lidu cestou klamstva) $)^{24}$ directed against Hlinka. According to Huska, Hlinka "defended the interests of high ecclesiastical hierarchy, he tried to distract discontented small farmers from the requirements for the separation between the church and landowners' land by instigating unrest against the Hungarian people, against the working class, the supposed 'Bolshevik gang', and via anti-Semitic attacks." 25 Such demagogic clichés and statements purposefully taken out of the context were to blacken Hlinka's efforts on behalf of the rights of the Slovak nation and made of him an anti-Communist and anti-Semitic instigator, and tempter of farmers. The statements about a Vatican plot against the working class in which Hlinka also participated hint of a conspiracy: "But Catholic hierarchy did not remain passive against this class. It tried to nip the emerging unity of the working-class movement in the bud with backstage intrigue. In particular, it gave its consent to the nomination of a young demagogic, seemingly persistent anti-Hungarian warrior and 'philanthropist' Andrej Hlinka to the parish office in Ružomberok. In fact, however, he was a loyal servant of Vatican belligerent

\footnotetext{
20 I. Stanek, Zrada a pád. Hlinkovští separatisté a tak zvaný slovenský stát, Praha 1958, 414 p.

21 I. Stanek, Zrada a pád. Hlinkovští separatisté a tak zvaný slovenský stát, Praha 1958, p. 37.

22 I. Stanek, Zrada a pád. Hlinkovští separatisté a tak zvaný slovenský stát, Praha 1958, p. 53.

23 I. Stanek, Zrada a pád. Hlinkovští separatisté a tak zvaný slovenský stát, Praha 1958, p. 57.

24 M. A. Huska, Proti ludu cestou klamstva, Banská Bystrica 1962, 130 p.

25 M. A. Huska, Proti lidu cestou klamstva, Banská Bystrica 1962, p. 15.
} 
clericalism, anti-people type guided by the Spišská Chapter of Cardinal-Primate and fanatic Jesuit priest - Bangh of Ostrihom." ${ }^{26}$ Hlinka is presented as a despot misusing the religious awareness of the Slovak people, and even as a man calling on his followers to murder. ${ }^{27}$ In other sections Hlinka is mentioned as a Vatican agent, a cruel, unscrupulous and selfish banker. A gradual turn towards greater objectivity appeared by the end of the 1960s. Juraj Kramer's Slovak autonomist movement in 1918-1929 (Slovenské autonomistické hnutie v rokoch 1918 - 1929) was published at the turn of decade. ${ }^{28}$ This work, in particular its introduction and conclusion, is characterized by ideological evaluations looking for class predetermination in the figure of Hlinka and in historical events. The core of the work as such tries to work more with a large number of historical sources, sometimes even without the needless mention of ideology.

The syntheses of so-called Czechoslovak history were also characterized by intentional withholding and one-sided negative interpretation. In the Overview of Czechoslovak history (Přehled československých dějin ${ }^{29}$, Hlinka is not mentioned either in connection with the Hungarian People's Party or in connection with the massacre in Černová. He is mentioned for the first time only in the period from 1911 to 1913 in connection with the breakup "of the Slovak bourgeois wing" and the renewal of the Slovak People's Party. In this interpretation of the Slovak politics, it was degraded to "fierce confessional demagogy and defence of the interests of ecclesiastical hierarchy." 30 The next volume of this synthesis evaluates Hlinka as a politician leading the reactionary clergy and discontented nationalistic bourgeoisie. The allegedly fascist nature of his political party has been one-sidedly emphasized. ${ }^{3}$

Since the mid-1960s, Slovak historiography has started to discuss more and seek new ways and interpretations. Several historians not satisfied with the schematization and ideological cliché of the 1950s came to the fore. They got the chance to express their opinions more freely during the short revival year of 1968. Of them, Július Mésároš should be mentioned in connection with the figure of A. Hlinka. His synthesis, History of Slovakia II, from 1848 to 1900 (Dejiny Slovenska II. Od roku 1848 - 1900), was published in 1968. Mesároš attracts attention on several fronts. For the first time since the end of the war, a portrait photograph of a young A. Hlinka was published in a Slovak book. Mésároš devoted quite a lot of space to Hlinka and objectively highlighted his positive traits: "He did not start his political career with a special ideology,

\footnotetext{
26 M. A. Huska, Proti l'udu cestou klamstva, Banská Bystrica 1962, p. 17 - 18.

27 M. A. Huska, Proti l'udu cestou klamstva, Banská Bystrica 1962, p. 74.

28 J. Kramer, Slovenské autonomistické hnutie v rokoch 1918 - 1929, Bratislava 1962, 482 p.

29 Přehled československých dějin. 1848 - 1918, t. 2, Praha 1960, p. 793 - 1362.

30 Přehled československých dějin. 1848 - 1918, t. 2, Praha 1960, p. 793 - 1362. p. 1020.

31 Přehled československých dèjin. 1918 - 1945, t. 3, Praha 1960, p. 57.
} 
and a deeper theoretical and philosophical thinking was far from his frame of mind. However, his personal organisational capabilities, and sense of detailed work became more apparent, which he was able to apply in practical life using adequate energy and ambition.... By his new approach to the national-revivalist, social and enlightenment work among the common people, Hlinka caused a real turn in the existing high politics of the Martin centre." Mesároš also provides two longer quotations from Hlinka's articles which characterize his social work and enlightenment activities, evaluating him as a leading personality of the Slovak Catholicism: "As a priest of the Christian confession he expected that in this manner, even without larger social and societal changes or reforms, he would manage to free the common people from social poverty, and at the same time win them over for the national movement ... towards the end of the century, he strongly advocated the idea of Czechoslovak solidarity promoting in particular the national-revivalist, enlightenment and cultural work of the Czech and Moravian clergy among people. Along with M. Kollár, R. Osvald, J. Milkin (Donoval) and others, Hlinka worked his way up to the position of a leading personality in Slovak Catholicism by his purposeful and energetic organisational work." ${ }^{32}$ In the spirit of Marxism, he then adds that "the world-view and profession of a small priest itself considerably determined and limited progressive efforts of the leading class of such a movement and prevented deeper insight into the social and societal and class problems of its era." ${ }^{33}$ As a historian, J. Mésároš suffered the consequences of his openness in his work during normalization. In 1970, by decision of the authorities of the Communist Party of Slovakia, he was excluded from the Communist Party of Slovakia (KSS) and removed as director of the Institute of History of the Slovak Academy of Sciences. He was not allowed to publish from 1972 to 1989.

Lubomír Lipták was another historian who expressed more openly his opinion on the figure of A. Hlinka in 1968. He was able to write in vivid even essayistic and nonconformist language destroying the dogmatic ideological vocabulary in historiography while still claiming allegiance to Marxism. Lipták refused to see history and its figures in just black and white. He manifested this belief to the fullest in his synthesis Slovakia in the 20th century (Slovensko $v 20$. storoči $)^{34}$ in which he devoted adequate space to the person of Andrej Hlinka. One quote is sufficient to reverse the existing official viewing of Hlinka: "This young priest, in whose mentality and political fate all virtues and vices of the Slovak national character, its strength and weakness seem to be embodied, was at that time just leaving the anonymity of being a local player to come

32 J. Mésároš, Dejiny Slovenska II. Od roku 1848 - do roku 1900. Bratislava 1968, p. 509 - 510.

33 Přehled československých dějin. 1848 - 1918, t. 2, Praha 1960, p. 793 - 1362. p. 510.

34 L'. Lipták, Slovensko v 20. storočí, Bratislava 1968, 365 p. 
to the fore of Slovak politics where he gradually became and has remained, possibly until now, its most noticeable figure. ${ }^{35}$ Moreover, he is speaking about bravery and tenacity in connection with Hlinka. This was a real "release of bewitchment" from the figure of Hlinka. Thus, Lipták presented Hlinka as a typical Slovak personality reflecting the Slovak national character; he not only was but remained the most noticeable (the most distinctive and striking) Slovak political personage. Lipták's criticism was focused on Hlinka's confessional rigidity but, from his Marxist position, also on the fact that Hlinka wanted to settle the unrest of masses within the existing social order. Lipták's book was crushed after the intervention of the five Warsaw Pact countries in August 1968. J. Mésároš and L. Lipták each wrote two chapters in the extensive synthesis Slovakia - History (Slovensko - Dejiny). ${ }^{36}$ This synthesis was completed in the spring of 1969, i.e. during the normalization period, but it had been created in the freer year of 1968. Mésároš worked out the period starting from the Austro-Hungarian Settlement up to World War I, Lipták from World War I till 1945; however, Lipták, who could not write under his own name, wrote under a pen name Ján Michalec. Upon political purges, Lipták had to leave the Institute of History of the Slovak Academy of Sciences in 1971 for the Historical Museum of the Slovak National Museum. He was placed under a full, and later partial, ban on publishing. Both historians - Mésároš and Lipták - used the opportunity to interpret Slovak history, including the figure of Hlinka, in a more vivid, flexible and objective manner, including his quotations. In their works, Mésároš and Lipták symbolically returned the figure of A. Hlinka to the interpretation of Slovak history. Thus they contributed to his preservation in the historical memory. The anthology of sources compiled by František Bokes - Documents concerning the Slovak national movement in 1848 - 1917 (Dokumenty k slovenskému národnému hnutiu v rokoch 1848 - 1914) 37 - was an important work providing information about Hlinka. It was the last volume of a larger project of an edition which had been started at the Slovak Academy of Sciences in 1962. The last volume was released during normalisation. Bokes noted in the introduction that he "... did not overlook even the first appearances of the young representatives of the Slovak national movement such as A. Hlinka and Milan Hodža." ${ }^{\text {8 }}$ Bokes included in the publication several

\footnotetext{
35 L'. Lipták, Slovensko v 20. storočí, Bratislava 1968, p. 32.

36 TIBENSKÝ, Slovensko. Dejiny. Bratislava : Obzor, 1971, 851 p.; 22,500 copies were published.

37 F. Bokes red., Dokumenty k slovenskému národnému hnutiu v rokoch $1848-1914$, t. 3, Bratislava 1972, 589 p.

38 F. Bokes red., Dokumenty k slovenskému národnému hnutiu v rokoch 1848 - 1914, t. 3, Bratislava 1972, p. 7.
} 
documents where Hlinka is mentioned, as well as a speech and an article written by him. ${ }^{39}$ This specialist publication had a rather low print run of 1000.

During the times of normalisation from the beginning of the 1970s, the ideological struggle and the forcible "atheization" of society intensified. In Slovakia, "reactionary clericalism" was proclaimed a serious danger. Such an ideological attack was directed against the figure of Andrej Hlinka, which was again passed over in silence or by onesided negative interpretations. If any historical work deviated even a bit from the accepted party line, it was crushed. Slovak Academy of Sciences historian Alena Bartlová's Participation of Hlinka's Slovak People's Party in the political development of Slovakia in $1930-1938^{40}$ is a clear example. This monograph was crushed immediately after its release in 1972 by order of the Communist Party Centre. In the 1970s and 1980s, the official historiography did not publish any special work on A. Hlinka. Periodical studies published in the Historical Journal, Historical Studies, and rare monographs analyzing Slovak politics at the turn of the 19th and 20th century can be considered some kind of progress in spite of the strong ideological pressure. A few examples are the publications by Jozef Butvin ${ }^{41}$, Milan Podrimavský ${ }^{42}$, J. Popély ${ }^{43}$ and Michal Potemra. ${ }^{44}$ A very important work was the synthesis History of Slovakia V (Dejiny Slovenska $\mathrm{V}) .^{45}$ The chapter devoted to the autonomist movement was drawn up by A. Bartlová. She tried to objectively capture the nature of the figure of Hlinka and the formation of the legend surrounding Hlinka. She concluded that Hlinka "entered the political arena in the new Czechoslovak state with aura of a martyr and fighter for the rights of the Slovak nation against Hungarian governmental circles, and the legend surrounding his personal participation in the tragedy in Černová. His sentencing to prison in Mírovo in 1919 on the grounds that, neglecting official emissaries representing Czechoslovakia in Paris, he tried to obtain support of the followers of his political concept for the solution of the Slovak issue was used by his political col-

39 F. Bokes red., Dokumenty k slovenskému národnému hnutiu v rokoch 1848 - 1914, t. 3, Bratislava 1972, Document No 411. A. Hlinka's letter of thanks to his voters of the Ružomberok electoral district at the occasion of the Hungarian Assembly in (p. 388 - 390), Document No 427a Extract from A. Hlinka's speech at the assembly of Liptov district about Slovak grievances (p. 448 - 449).

40 A. Bartlová, Účast'HSL'S na politickom vývoji Slovenska v rokoch 1930 - 1938, Bratislava 1972.

41 J. Butvin, “Slovenské národnopolitické hnutie v rokoch 1890 - 1898”, Historický časopis, 1983, t. 31; J. Butvin, "Hlasisti, vznik slovenského klerikálneho a maloagrárneho hnutia v rokoch 1898 - 1904”, Historický časopis, 1983, t. 31.

42 M. Podrimavský, “Program Slovenskej národnej strany v rokoch 1900 - 1914”, Historický časopis, 1977, t. 25; M. Podrimavský, Slovenská národná strana v druhej polovici XIX. storočia, Bratislava 1983, 241 p.

43 G. Popély, Počiatky politického klerikalizmu v Uhorsku a proces kryštalizácie Slovenskej l'udovej strany. Kandidátska dizertačná práca. Bratislava, 1977; G. Popély, "Zichyho strana a nacionálno-klerikálne hnutie na Slovensku v rokoch 1895 - 1905”, Historický časopis, 1978, t. 26.

44 M. Potemra, “Uhorské volebné právo a volby na Slovensku v rokoch 1901 - 1914”, Historický časopis, 1975, t. 23.

45 Dejiny Slovenska V (1918 - 1945), Bratislava 1985, 611 p. 
leagues and by himself to create a heroic epos. A. Hlinka was skilful in reminding his voters and supporters of all such political and personal grievances; moreover, he was a good orator, able to make use of his knowledge of life and everyday worries of the Slovak common people." ${ }^{36}$

The enormous political pressure which prevented historic science from doing research freely, on the one hand, was reflected on the other in the interest in the person of Hlinka in samizdat literature on the other. When Mikhail S. Gorbachev came to power in the Soviet Union in 1985, the communist leadership in the Czechoslovak Republic formally recognized "perestroika" and "glasnost" but, in fact, refused to open sensitive historical themes. Thus, the dogmatic ideological approach to history was still in effect. A case in point is the dictionary entry for Andrej Hlinka in 1987's Slovak Biographic Dictionary (Slovenský biografický slovnik). This entry evaluated Hlinka as a clerical-nationalistic politician who knowingly misused the religious feelings of the faithful for his own purposes. "His political development was more and more predominated by anticommunism, nationalism, anti-Czech chauvinism, antiSemitism, which acquired its synthetic form in a special Slovak sort of clerical fascism, to the constitution of which he contributed significantly." ${ }^{37}$ Hlinka was described as a representative of "the most reactionary bourgeois forces" and his party as "the most reactionary party of the Slovak bourgeoisie". ${ }^{38}$ Such an evaluation is the Communist reckoning with a political and ideological rival, rather than a factual dictionary entry.

The public were anxious for the alternative information provided in samizdat literature. In this regard, the activities of Ivan Polanský, ranking among the most agile editors of samizdat in Slovakia, were the most important in connection with Hlinka. Polanský was the co-author of a samizdat series of yearbooks Historical Notebook (Historický zápisnik) devoted to Slovak historical figures. When considering whether to devote the first volume to the figure of Andrej Hlinka or Jozef Tiso, the president of the first Slovak Republic in 1939-1945, he decided to publish the first samizdat about Tiso. His reasoning was that if he published Hlinka first and was detained, he would not be able to publish the Tiso volume. Tiso was a more sensitive and explosive theme. When the Historical Notebook (Historický zápisnik) devoted to Tiso was published in 1986, the Communist Intelligence Service failed to identify the author. Therefore, Polanský had enough time to get ready and, in 1987, publish the second volume of the Historical Notebook (Historický zápisnik) which was devoted to Andrej Hlinka. He specified two main reasons for publishing that samizdat: due to "the permanent

\footnotetext{
46 Dejiny Slovenska V (1918 - 1945), Bratislava 1985,, p. 92 - 93.

47 Slovenský biografický slovník, t. 2, Martin 1987, p. 338.

48 Slovenský biografický slovník, t. 2, Martin 1987,, p. 339.
} 
pressure of mass media which have been systematically falsifying our Slovak history for more than 40 years with fiction, half-truths and explicit lies ..." ${ }^{49}$ and for love of truth and justice. I. Polanský compared the unfavourable situation of the misinterpretation of Slovak history with the better situation in Poland: "Teachers active in civil service there are not afraid to tell their students the truth about their history during classes, trips, walks, etc., just like parents and other educators of young people”. ${ }^{50}$ The introductory 17-page historical study gives a concise overview of A. Hlinka's life. It evaluates him as the most important personage of the 1st half of 20th-century Slovak history of. It is written in a popular style for the target audience - the Slovak younger generation. It is not criticism of Hlinka, but an apology of his politics, which can be explained by the ideological pressure dominating society at that time. The rest of the samizdat text contained examples of contemporaries' opinions on A. Hlinka, poems and a mosaic of Hlinka's quotations. Officers of the Communist Intelligence Service performed a search of Polanskýs house in November 1987. They arrested and accused him of subversion of the Republic. Investigators did not consider the whole case as an effort to reveal tabooed historical themes to the public in times of the so-called "glasnost". On the contrary, they presented Polanský as a political extremist. His trial was held before the Regional Court in Banská Bystrica on 13, 14 and 17 June 1988. ${ }^{51}$

Much space for the analysis of the figure of A. Hlinka was created in foreign democratic countries, where many members of the Slovak intelligentsia had emigrated in three waves - in 1945, 1948 and 1968. It is a paradox that Slovaks in exile did not use such space sufficiently. It appears that no historian tried to work out Hlinka's life comprehensively. Publication activities of the Slovak diaspora focused on contributions published on anniversaries of A. Hlinka's birth or death, and on contributions in a memoir-style. The largest volume about A. Hlinka to be published in exile is Anton Polák's Msgr. Andrez Hlinka. II. De geschiedenis van Slovakije. (Msgr. Andrew Hlinka. II History of Slovakia. $)^{52}$ This volume focused on the basic facts of A. Hlinka's life: moreover, its author was not a historian. Anton Mak wrote a serialized biographic column entitled Andrej Hlinka for the newspaper The American Slovak (Americký Slovák) published in the USA. This is also a populared depiction of A. Hlinka's life drawn up by a non-historian. Slovak expatriate in Canada, teacher Ján Eliášs book

49 Zbierka autora: Historický zápisník, č. 1, 1987. Úvodom.

50 Zbierka autora: Historický zápisník, č. 1, 1987. Úvodom.

51 I. Polanský was sentenced to 4 years of unconditional imprisonment. The Appellate Superior Court confirmed the initial judgment on 30/08/1988. Only the preselected public could attend the trial. Based on amnesty Polanský was granted remission of 2 years of imprisonment. He was released from prison on 15 Dec 1988. See: J. Šimulčík, Svetlo z podzemia, Bratislava 1997, p. 84 - 85. A. Hlinka, Sila slabých a slabost silných, Zagreb 1989, p. 337 - 339.

52 A. Polak, Msgr. Andrez Hlinka. II. De geschiedenis van Slovakije, Brussel 1960, 40 p. 
Andrej Hlink $a^{53}$ consists of two parts: the first, a popularized biography; the second, personal memories of Hlinka from several members of the Slovak diaspora.

In 1984, a more extensive work was to have been published in exile to mark the 120th anniversary of A. Hlinka's birth. President of the "Foreign Slovak Source" (Zahraničná Matica slovenská), Msgr. František Fuga, who had charged literary historian Ján Meštanč́k to do this job, died. F. Fuga continued the work alone and was later joined by Jozef Kirschbaum. The book, Andrej Hlinka in words and picture (Andrej Hlinka v slove a obraze), ${ }^{54}$ was published as an anthology of various texts about Hlinka, reflections, essays, memoirs and speeches even from after the fall of the communist regime. The book contains two contributions from historians in exile. Milan S. Durica contributed with the study "The Pioneer of Social Justice" (Priekopnik sociálnej spravodlivosti) dealing with the social engagement of A. Hlinka in Hungary. The other exiled historian, František Vnuk, wrote a short reflection essay on "Andrej Hlinka and the Slovak young generation" (Andrej Hlinka a mladé slovenské pokolenie) in which he highlighted the special relationship Hlinka had with the younger generation. Both contributions are popular in nature nature. Moreover, F. Vnuk published a brief popular biography of A. Hlinka covering the period after 1926 up until his death in 1938. It was a follow-up to a brief biography written by K. Sidor and published in the USA in 1926 and republished as a part of Vnuk's book. On F. Vnuk's initiative, the biography he had written was combined with Sidor's brief biography of 1926 and published as a separate publication entitled For God and the Nation ( $\mathrm{Za}$ Boha a národ). ${ }^{55}$ Only the study by the Carpathian-German historian Michael Schwartz, who was of Slovak origin and lived in exile from 1945, can be considered an extensive scientific work by a historian in exile. Schwartz's study was Hlinkas Kampf gegen den Prager Zentralismus. (Hlinka's Struggle against Prague Centralism). ${ }^{5}$

A fundamentally and qualitatively new situation for Slovak historiography came about after the fall of the Communist regime in 1989. Andrej Hlinka became a newly discovered theme of the Slovak historiography. On 20 September 1991, the first scientific symposium of historians was held in Bratislava, devoted entirely to the topic of Andrej Hlinka and his role in Slovak history. The proceedings entitled Andrej Hlinka and his role in Slovak History (Andrej Hlinka a jeho miesto v slovenských dejinách $)^{57}$ was published as a result of this event. It contains twelve expert studies and two speeches.

\footnotetext{
53 J. Eliáš red., Andrej Hlinka, Winnipeg 1983, 347 p.

54 J. Kirschbaum, F. Fuga red., Andrej Hlinka v slove a obraze, Toronto 1991, 349 p.

55 K. Sidor, F. Vnuk, Za Boha a národ. Náčrt životopisu Andreja Hlinku, Toronto, Bratislava, 1990, 71 p.

56 M. Schwartz, Hlinkas Kampf gegen den Prager Zentralismus. In: Slowakei, roč. 9, 1971, p. 27 - 56.

57 F. Bielik, Š. Borovský red., Andrej Hlinka a jeho miesto v slovenských dejinách, Bratislava 1991, 157 p.
} 
Historian Alena Bartlovás book Andrej Hlink $a^{58}$ was published the same year. It was the first book publication by a domestic Slovak historian comprehensively capturing the whole life of A. Hlinka. The Slovak historian Roman Holec devoted much space to A. Hlinka in his monograph Černová and Slovak Society (Černová a slovenská spoločnost).${ }^{59}$ Afterwards, the monograph Andrej Hlinka - the Champion of the Slovak Nation (Andrej Hlinka, tribún slovenského národa) ${ }^{60}$ by František Vnuk was published. It was a popularizing and educational monograph, and so far the most extensive work devoted to the personage of Hlinka done by one historian. Historian F. Vnuk supplemented the biography of Hlinka written earlier by journalist Karol Sidor in 1934 and published Andrej Hlinka 1864 - $1938 .{ }^{61}$ Historical research regarding the figure of Hlinka moved ahead. An international scientific conference dealing with the theme The Personage of Andrej Hlinka (Osobnost' Andreja Hlinku) (1864 - 1938) was held on 20 October 2008 in Bratislava. One year later, a collective monograph by Róbert Letz and Peter Mulík, Views of the Person of A. Hlinka (Pohliady na osobnost' A. Hlinku) ${ }^{62}$, was published. The work contains 17 papers by historians and brings new knowledge of historical science about A. Hlinka.

Along with original scientific studies and monographs, historical research attempted to make available the sources concerning the life of A. Hlinka. Historians Peter Olexák and Anna Safanovičovảs Anthology of periodical and newspaper articles of Andrej Hlinka (Antológia časopiseckých a novinových clánkov Andreja Hlinku. ${ }^{63}$ was published in 2013. It contains a selection of 63 periodical and newspaper articles by Andrej Hlinka without commentary. Andrej Hlinka in the light of documents (Andrej Hlinka vo svetle dokumentov). ${ }^{64}$ by Róbert Letz was published one year later. It contains a set of 59 historical sources concerning A. Hlinka. Andrej Hlinka and Slovak Catholics as seen by the Holy See 1918 - 1927 (Andrej Hlinka a slovenskí katolíci očami Svätej stolice 1918 - 1927) ${ }^{65}$ by the Slovak historian Emília Hrabovec was published on the occasion of the 140th anniversary of A. Hlinka's birth.

If we are to evaluate the quality of publications devoted to the figure of A. Hlinka by Slovak historiography after 1989, we can declare the end of "silence with respect to Hlinka", as well as the end of the one-sided negativistic evaluation by serious

\footnotetext{
58 A. Bartlová, Andrej Hlinka, Bratislava 1991, 117 p.

59 R. Holec, Tragédia v Černovej a slovenská spoločnost', Martin, 1997, 270 p.

60 F. Vnuk, Andrej Hlinka, tribún slovenského národa, Bratislava 1998, 165 p.

61 K. Sidor, F. Vnuk, Andrej Hlinka 1864 - 1938, Bratislava 2008, 984 p.

62 R. Letz, P. Mulík a kol., Pohl'ady na osobnost' A. Hlinku, Martin 2009, 278 p.

63 P. Olexák, A. Safanovičová red., Antológia časopiseckých a novinových článkov Andreja Hlinku. Martin 2013, 261 p.

64 R. Letz, Andrej Hlinka vo svetle dokumentov, Bratislava 2014, 357 s.

65 E. Hrabovec, Andrej Hlinka a slovenskí katolíci očami Svätej stolice 1918 - 1927, Bratislava 2014, 128 p.
} 
historians. the last decade of the 20th century was characterized by the demand for basic information about Hlinka. Several historians met that demand by popularizing works. This phenomenon was determined by the societal situation before 1989, on the one hand, but also by an insufficient working through the topic, on the other. We can also see a gradual trend away from the popularizing works of the 1990s towards scientific works. Since the 1990s, both the domestic and foreign source base concerning A. Hlinka has gradually emerged and been evaluated, and as such is not yet complete. At the same time, in Slovak historiography, we can observe the gradual transformation from national-apologist interpretations to interpretations based upon a factual critical portrayal of the figure of Hlinka. Historiography still has a lot to do in regard to the figure of Hlinka due to the continual absence of a more extensive critical monograph which would integrate the results of the latest knowledge. This also involves a more comprehensive understanding of the man in connection with the two periods separated by the year 1918. Actually, historiography has paid more attention to the Hlinka before 1918. Consequently, Hlinka is seen from two different angles - the one, better known and understood before 1918 and the other, less known and insufficiently understood after 1918. In the case of Hlinka, such a dichotomy is highly noticeable. However, this is also the challenge for the future direction of research devoted to the personage of Andrej Hlinka.

\section{TRANSLATION: Evo SCIRANKOVÁ}

BIBLIOGRAPHY

Bartlová A., Andrej Hlinka, Bratislava, 1991.

Bartlová A., Účast'HSL'S na politickom vývoji Slovenska v rokoch 1930 - 1938, Bratislava, 1972.

Bielik F., Borovský Š., (red.), Andrej Hlinka a jeho miesto v slovenských dejinách, Bratislava, 1991.

Bokes F., (red.), Dokumenty k slovenskému národnému hnutiu v rokoch 1848 - 1914, t. 3, Bratislava, 1972. Bokes F., Dejiny Slovákov a Slovenska od najstarších čias až po prítomnost', Bratislava, 1946.

Bratislava, 1977.

Butvin J., Hlasisti, vznik slovenského klerikálneho a maloagrárneho hnutia v rokoch 1898 - 1904, „Historický časopis", 1983 , t. 31 .

Butvin J., Slovenské národnopolitické hnutie v rokoch 1890 - 1898, „Historický časopis”, 1983, t. 31.

Cháb V., Andrej Hlinka. Život a politika, Praha, 1934.

Dejiny Slovenska V (1918 - 1945), Bratislava, 1985.

Eliáš J., (red.), Andrej Hlinka, Winnipeg, 1983.

Fagula L.G., Andrej Hlinka. Bratislava 1943.

Hlinka A., Sila slabých a slabost' silných, Zagreb, 1989.

Holec R., Tragédia v Černovej a slovenská spoločnost', Martin, 1997.

Holotík L'. (red.), Dejiny Slovenska, Bratislava, 1955.

Hrabovec E., Andrej Hlinka a slovenskí katolíci očami Svätej stolice 1918 - 1927, Bratislava, 2014. 
Hrušovský F., Slovenské dejiny. Turčiansky Sv. Martin, 1939.

Huska M.A. , Proti ludu cestou klamstva, Banská Bystrica, 1962.

Kirschbaum J., Fuga F., (red.), Andrej Hlinka v slove a obraze, Toronto, 1991.

Kramer J., Slovenské autonomistické hnutie v rokoch 1918 - 1929, Bratislava, 1962.

Letz R.,, Andrej Hlinka vo svetle dokumentov, Bratislava, 2014.

Letz R.,Mulík P, Pohl'ady na osobnost' A. Hlinku, Martin, 2009.

Lipták L., Slovensko v 20. storočí, Bratislava, 1968.

Literárny archív Slovenskej národnej knižnice Martin, fond F. Hrušovský - dodatky, k. 1. F. Hrušovský: Prečo sa dnes na Slovensku nespomína Andrej Hlinka. (Rukopis) ? 9. 1., 1946.

Mésároš J., Dejiny Slovenska II. Od roku 1848 - do roku 1900. Bratislava, 1968

Olexák P., Safanovičová A., (red.), Antológia časopiseckých a novinových článkov Andreja Hlinku. Martin, 2013.

Podrimavský M., Program Slovenskej národnej strany v rokoch 1900 - 1914, „Historický časopis”, 1977, t. 25 .

Podrimavský M., Slovenská národná strana v druhej polovici XIX. storočia, Bratislava, 1983.

Polak A., Msgr. Andrez Hlinka. II. De geschiedenis van Slovakije, Brussel, 1960.

Popély G., Počiatky politického klerikalizmu v Uhorsku a proces kryštalizácie Slovenskej l'udovej strany, Kandidátska dizertačná práca czy dysertacja doktorska

Popély G., Zichyho strana a nacionálno-klerikálne hnutie na Slovensku v rokoch 1895 - 1905, „Historický časopis", 1978, t. 26.

Potemra M., Uhorské volebné právo a volby na Slovensku v rokoch 1901 - 1914, „Historický časopis”, 1975, t. 23.

Přehled československých dèjin. 1848 - 1918, t. 2, Praha, 1960.

Přehled československých dějin. 1848 - 1918, t. 3, Praha 1960.

Schwartz M., Hlinkas Kampf gegen den Prager Zentralismus, „Slowakei”, 1971/9

Sidor K. Zápisky z Mírova, Bratislava, 1941.

Sidor K., Andrej Hlinka (1864 - 1926), Bratislava, 1934.

Sidor K., Andrej Hlinka, Bratislava, 1924.

Sidor K., Vnuk F., Za Boha a národ. Náčrt životopisu Andreja Hlinku, Toronto, Bratislava, 1990.

Sidor K.,Vnuk F., Andrej Hlinka 1864 - 1938, Bratislava, 2008.

Šimulč́́k J., Svetlo z podzemia, Bratislava, 1997.

Slovenský biografický slovnik, t. 2, Martin, 1987.

Stanek I., Zrada a pád. Hlinkovští separatisté a tak zvaný slovenský stát, Praha, 1958.

Tibenský J., Dejiny Slovenska slovom i obrazom, I. Bratislava, 1973.

Vnuk F., Andrej Hlinka, tribún slovenského národa, Bratislava, 1998. 